University of Wyoming College of Law

Law Archive of Wyoming Scholarship

$12-7-2007$

\title{
Appellate Record in Rubin vs. Old York Department of Social Services
}

Kenneth D. Chestek

University of Wyoming College of Law, kchestek@uwyo.edu

Follow this and additional works at: https://scholarship.law.uwyo.edu/other

\section{Recommended Citation}

Chestek, Kenneth D., "Appellate Record in Rubin vs. Old York Department of Social Services" (2007). Other Publications and Activities. 3.

https://scholarship.law.uwyo.edu/other/3

This Article is brought to you for free and open access by the UW College of Law Faculty Scholarship at Law Archive of Wyoming Scholarship. It has been accepted for inclusion in Other Publications and Activities by an authorized administrator of Law Archive of Wyoming Scholarship. 
No. 07-2261

IN THE COURT OF APPEALS OF OLD YORK

\author{
MARGARET RUBIN, \\ Petitioner,
}

V.

\title{
OLD YORK COUNTY DEPARTMENT OF SOCIAL SERVICES AND DELIA CLARKE,
}

Respondents.

\section{On Appeal from the Superior Court of Old York County}

\section{RECORD OF PROCEEDINGS}

\footnotetext{
Copyright @ 2004 and 2007 by Kenneth D. Chestek and James D. Dimiti, Indiana University School of Law-Indianapolis Permission is hereby granted to use this record and the accompanying brief in classroom instruction or for other scholarly undertakings.

This record is part of a project studying the relationship of narrative reasoning to rule-based reasoning. I analyze the narrative element of the brief written for this mock case in my article The Plot Thickens: The Appellate Brief as Story. That article can be downloaded from SSRN at this link: http://papers.ssrn.com/sol3/papers.cfm?abstract_id=998388. The appellate brief for this mock case can be downloaded at http://papers.ssrn.com/sol3/papers.cfm?abstract_id=998325.
} 


\section{TABLE OF CONTENTS}

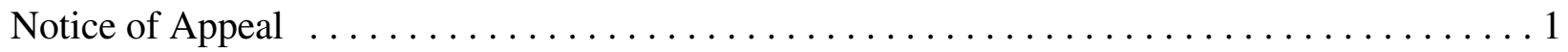

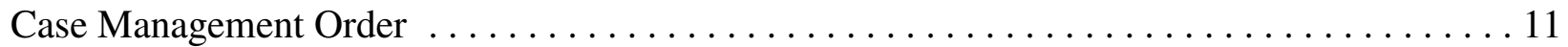

Transcript of the Deposition of Margaret Rubin $\ldots \ldots \ldots \ldots \ldots \ldots \ldots \ldots \ldots \ldots \ldots \ldots$

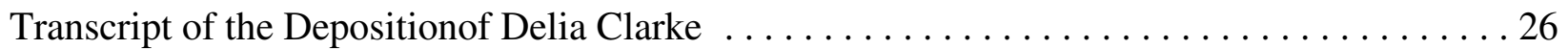

Order and Judgment $\ldots \ldots \ldots \ldots \ldots \ldots \ldots \ldots \ldots \ldots \ldots \ldots \ldots \ldots \ldots \ldots \ldots \ldots \ldots \ldots \ldots \ldots \ldots$

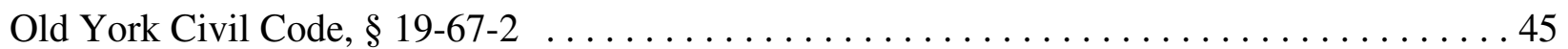


IN THE SUPERIOR COURT OF OLD YORK COUNTY

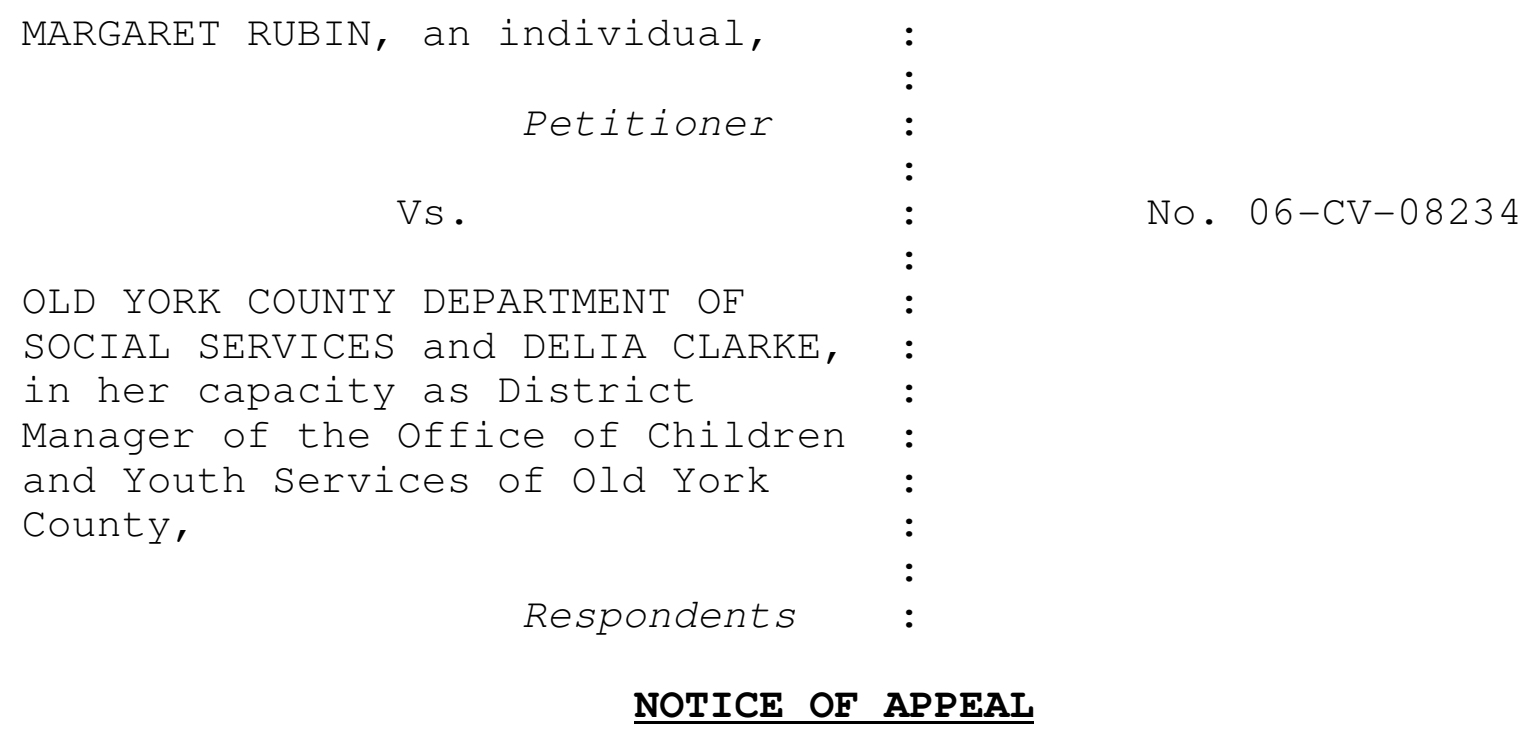

3. Respondent Delia Clarke is an adult individual and an employee of the respondent Old York County Department of Social Services. She is made a party to this appeal in her capacity as District Manager of the Office of Children and Youth of Old York County, a division of the Old York County Department of Social Services.

4. This is an appeal from a decision of OYCDSS, as to which this Court has jurisdiction pursuant to OYCC \$ 4-12-02. 
5. Rubin is the mother of Jonathan Kohler. Jonathan's biological mother, Francine Kohler, who had also resided in the same household as Jonathan and Rubin, was killed in a motor vehicle accident on September 9, 2006.

6. At the time of Francine Kohler's death, she and Rubin were partners in a valid civil union performed on July 13, 2000 , in the state of Vermont.

7. On August 18, 2003, Jonathan Swift Kohler was born to the union of Francine Kohler and Margaret Rubin.

8. On September 19, 2006, Stella Kohler, Francine's mother, wrote a letter to OYCDSS alleging that Jonathan Kohler was at risk because he was living with a non-blood relative. 9. On Sept. 21, 2006, OYCDSS issued a rule on Rubin to show cause why Jonathan Kohler should not be determined to be a dependent child and placed in foster care.

10. On September 30, 2006, Rubin responded that Jonathan Kohler was not a dependent child, but the legal child of Rubin pursuant to her civil union with Francine Kohler performed in Vermont. Rubin simultaneously filed a petition with OYCDSS to adopt Jonathan.

11. On December 3, 2006, respondent Clarke visited Rubin's home as part of the home study attendant to a petition for adoption .

12. On December 17, 2006, Clarke, in her official capacity, 
filed her report with OYCDSS. A copy of the relevant portions of that report are attached hereto as Appendix A.

13. Clarke's report finds, inter alia, that Jonathan is safe and happy, and that Rubin's home is appropriate and welltended.

14. On December 19, 2006, OYCDSS denied the petition for adoption. A copy of that order is attached hereto as Appendix B.

15. The OYCDSS order declines to honor the civil union entered into in Vermont, saying that homosexual marriages are not valid in Old York.

16. The order also denied the adoption petition on the basis that Rubin is a lesbian. The order cites OYCC $\$ 19-67-2(B)$, which explicitly provides that "homosexuals are not eligible to adopt" in Old York.

17. OYCC $\$ 19-67-2(B)$ is unconstitutional in that it violates the Fourteenth Amendment to the United States Constitution, in the following particulars:

a. It violates Rubin's fundamental right to privacy under the Due Process Clause.

b. It violates Rubin's and Jonathan Kohler's fundamental right to family integrity under the Due Process Clause.

c. It illegally discriminates against Rubin on the basis of sexual orientation in violation of the Equal 
Protection Clause.

18. The Order of OYCSS dated Dec. 19, 2006 also improperly ignores the Full Faith and Credit Clause of United States Constitution (Art. IV, \$ 1 ).

WHEREFORE the Petitioner respectfully requests that this Court

a. Vacate the Order of Dec. 19, 2006, and issue an order declaring that Petitioner is the mother of Jonathan Kohler pursuant to the civil union between Francine Kohler and Margaret Rubin entered into by them on July 13, 2000; or b. In the alternative, reverse the Order of Dec. 19, 2006 and allow the adoption of Jonathan Kohler by Petitioner.

Respectfully submitted

/s/ Ellen Jones

Ellen Jones, Esq.

Counsel for Petitioner 
APPENDIX A

\title{
COUNTY OF OLD YORK DEPARTMENT OF SOCIAL SERVICES OFFICE OF CHILDREN AND YOUTH
}

\author{
Report of Home Visit
}

${ }^{* * *}$ CONFIDENTIAL ${ }^{* * *}$

Report date:

Reporting Officer:

Prospective adoptive parent(s):

Home visit date:
Dec. 17, 2006

Delia Clarke

Margaret Rubin

Dec. 3, 2006

This is a report prepared in connection with a petition for adoption of Johnnie Kohler, age 3, by Margaret Rubin. Johnnie Kohler has been previously determined to be a dependent child after the death of his natural mother, Francine Kohler, in an automobile accident. Francine was unmarried, and the father is unknown since Francine became pregnant through in vitro fertilization using an anonymous sperm donor.

This office conducted an investigation leading up to a finding of dependency after Stella Kohler, Francine's mother, alerted the Office of Children and Youth that her grandson Johnnie was living with a woman, Margaret Rubin, who was not related to him. Upon verifying these facts, this office declared Johnnie to be a dependent child and asked Margaret Rubin to deliver him to our custody. She responded by claiming to be his mother and that he was therefore not a "dependent child." She also filed this petition for adoption.

\section{Applicant information}

Applicant Margaret Rubin is a 41-year-old woman in apparent good health; she reports no chronic illnesses or mental impairments. No mental or emotional problems manifested themselves during the home study.

Applicant lives in a home at 242 Kiler Way, Old York City, Old York. She reports (confirmed by courthouse records) that she was a co-tenant with the 
right of survivorship with Francine Kohler; upon the death of Francine in July 2006 the property therefore vested in applicant in fee simple. There is no mortgage on the property. A check of courthouse records reveals no liens of any sort on the property, nor any litigation or any other suggestion of financial difficulties.

Applicant is an adjunct professor of art at Old York University. She had previously been a tenured full-time professor at Old York before the birth of Johnnie Kohler; applicant reports that, at the time Francine Kohler gave birth to Johnnie, she agreed to move to an adjunct position, teaching one evening course per semester, so that she could stay home during the day to raise Johnnie.

Francine Kohler had been applicant's life partner. Applicant reports that she and Francine had obtained a civil union certificate from the state of Vermont in 2000. She also reports that in 2002 Francine agreed to become pregnant through in vitro fertilization, which was successful. The sperm used in the process was donated by an anonymous man. Johnnie was born to Francine on August 18, 2003.

Francine Kohler was killed in an automobile accident on September 9, 2006. Francine left no will; however, she had designated Margaret Kohler as her sole beneficiary on her life insurance policy. That policy paid \$1 million in death benefits to applicant, and applicant has invested that sum of money. Investment income from those insurance proceeds now provide most of her financial support. Applicant has invested the proceeds primarily in bonds and other income-producing assets, and expects a return of approximately $\$ 40,000$ per year from that fund. Together with her other income from sale of artwork, teaching and other investments, applicant expects a net annual income of between $\$ 55,000$ and $\$ 60,000$ in the next twelve months.

\section{Finding of dependency}

Since applicant has no blood relationship with Johnnie, she has no legal relationship with him. Since Old York law does not allow homosexuals to marry, Old York courts do not recognize civil unions between same-sex couples performed in other jurisdictions, or performed without a license in this jurisdiction. Pursuant to OYCC 6-14-1, therefore, Johnnie Kohler is a dependent child. 


\section{Report of home visit}

Margaret Rubin has filed a petition to adopt Johnnie. The adoption application requires the applicant to disclose whether the applicant is a homosexual; however applicant did not answer that question. As a result, this office decided to process the adoption petition in the usual course, and attempt to determine during the home visit whether applicant is homosexual.

This officer met with applicant on Dec. 3, 2006 in her home. Johnnie was present for most of the interview; I met privately with applicant outside of the presence of Johnnie for approximately an hour when Johnnie took his afternoon nap.

Johnnie appeared shy around me at first, which is entirely appropriate behavior for a child of his age. However, once I had sat quietly for a while and chatted with applicant, he seemed to understand that I was not a threat to him and he relaxed a bit. Once applicant let him know that it was okay to talk with me, he did so. He seemed quite attached to applicant, and she to him.

The home was very large and well-appointed. It had a large yard with a fence enclosing the back yard; a small swingset and a sandbox were in the back yard. There were toys all around the house, which Johnnie began to play with while I was talking with applicant. According to applicant, she and Johnnie have lived in this house since Johnnie was born.

After Johnnie went down for his nap, I spoke to applicant about her relationship with Francine Kohler. Without hesitation she referred to Ms. Kohler as her "partner," and acknowledged that they had a domestic relationship. She did not answer questions about her sexual activities with Ms. Kohler, but did state that she "loved" her partner and that they were a "committed couple." She said that she and Ms. Kohler had traveled to Vermont in the summer of 2000 to go through a civil commitment ceremony. When I asked her directly if she were a lesbian, she politely, but firmly, declined to answer the question because she deemed it "irrelevant" to her fitness as a mother.

\section{Outside investigation}

A review of records at the courthouse turned up no information about applicant. She appears to be financially stable and has no criminal record within Old York County. 
This officer interviewed Stella Kohler at Stella's home. Stella is 76 years old, and was Francine Kohler's mother. She told me that Francine had never married, but that she had "taken up with a series of women," the latest of whom was applicant. She made it clear that she did not approve of the relationship between Francine and applicant, and she expressed her fear that "my grandson is going to turn out queer" if applicant were permitted to raise him.

Stella was in apparent poor health. She appeared frail and walked with a cane. She said she had severe asthma and other chronic ailments. She said that while she loved Johnnie "with all my heart," she said she was not physically able to take care of a "bounding young boy." She is a widow and Francine was her only child; thus, there appear to be no blood relatives of Johnnie willing or able to take care of him.

This officer also interviewed four neighbors of applicants on Kiler Way. All of them said that Francine and applicant had been good neighbors. Most of them said they mostly saw applicant, and not Francine, taking Johnnie for walks through the neighborhood in his stroller. One neighbor, Jody Smith, said she had a four-year-old son and that her son and Johnnie played together often. She said Johnnie appeared to be well-adjusted and "just a totally normal kid." She said she did not express any alarm or worry about the fact that applicant was a lesbian. "She always seems like such a nice person," Smith reported. Smith said she never worried about allowing her son to play at applicant's house unsupervised by Smith; she said she had every confidence that applicant was "a good mother."

\section{Findings and recommendation}

It is this officer's finding that the home environment provided for Johnnie is safe and appropriate in all respects save one. It appears that Johnnie is wellloved, and that he loves the applicant, and that the attachment is normal for a child of this age and in this circumstance. Applicant has the financial means to support Johnnie and the clear desire to do so. There is no evidence of mistreatment, abuse, neglect or any other condition detrimental to Johnnie's well-being.

However, this officer also finds evidence that applicant is a lesbian. Since OYCC 19-67-2(d) prohibits homosexuals from adopting, this officer recommends that the petition for adoption be denied, and that Johnnie be placed in an appropriate approved foster home. 


\title{
APPENDIX B
}

\section{COUNTY OF OLD YORK DEPARTMENT OF SOCIAL SERVICES OFFICE OF CHILDREN AND YOUTH}

\author{
Eleanor Bryant, Director
}

Dec. 19, 2006

Ms. Margaret Rubin

242 Kiler Way

Old York City, Old York

Re: Petition for adoption of Jonathan Kohler

Dear Ms. Rubin:

It is my duty to inform you that, after conducing a home visit and the further investigation required by OYCC 6-15-6.2, this office has DENIED your petition to adopt Jonathan Kohler.

As you know, OYCC 19-67-2(d) provides that homosexual individuals are not eligible to adopt in Old York. Our investigation turned up credible evidence that you are homosexual; therefore by law this office cannot approve your petition.

Please contact this office immediately to make arrangements for our staff to take custody of Johnnie. If you fail to do so, we will be forced to seek a court order directing you to relinquish custody. It is our sincerest hope that, for the sake of the child, this matter can be concluded in a respectful and nonconfrontational manner.

I thank you for your cooperation.

Very truly yours,

Eleanor Bryant, Director 
Old York County Department of Social Services 
IN THE SUPERIOR COURT OF OLD YORK COUNTY

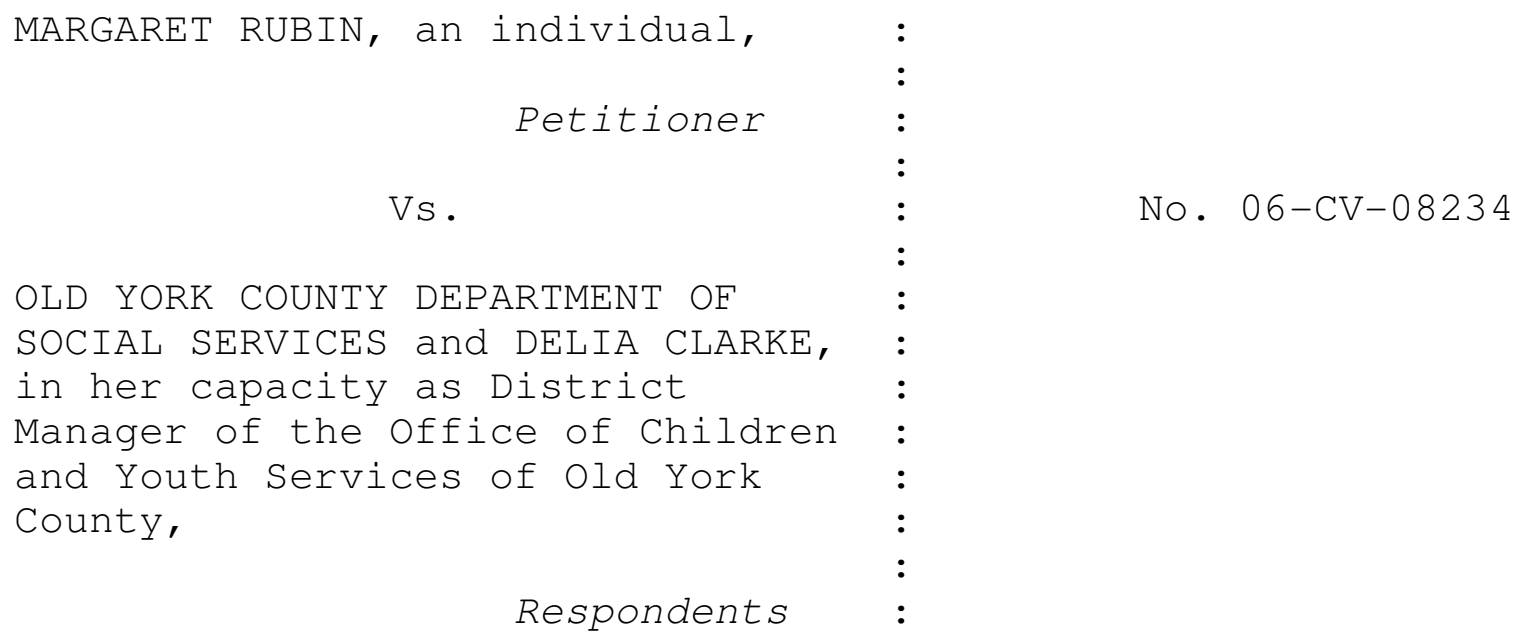

\title{
CASE MANAGEMENT ORDER
}

AND NOW, to-wit, this 8th day of January, 2007, it appearing that the record is incomplete in regard to certain aspects of this case, it is hereby ORDERED that Petitioner and Respondent shall have 30 days in which to complete discovery in this case, limited to the following matters:

A. The alleged existence of a "civil union" between Petitioner and the ward's mother, Francine Kohler.

B. The propriety of the placement of Johnnie Kohler in the home of Petitioner.

\author{
BY THE COURT \\ /s/Malcolm McClaren \\ Hon. Malcolm McClaren, J.
}




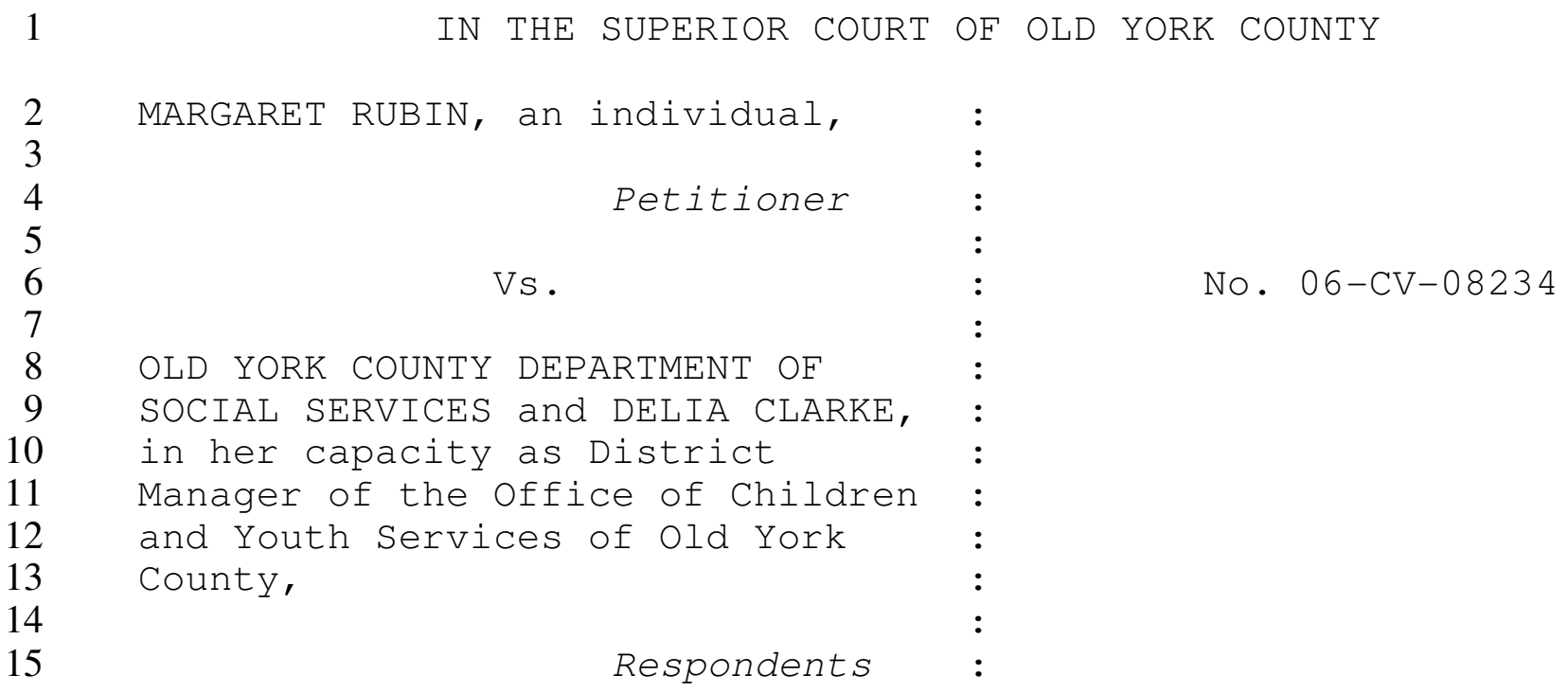

$\begin{array}{lllllllllllllllllllllllll}16 & \mathrm{~T} & \mathrm{~A} & \mathrm{~N} & \mathrm{~S} & \mathrm{C} & \mathrm{R} & \mathrm{I} & \mathrm{P} & \mathrm{T} & \mathrm{O} & \mathrm{F} & \mathrm{T} & \mathrm{H} & \mathrm{E} & \mathrm{D} & \mathrm{E} & \mathrm{P} & \mathrm{O} & \mathrm{S} & \mathrm{I} & \mathrm{T} & \mathrm{I} & \mathrm{O} & \mathrm{N}\end{array}$ O F $M A R G A R E R \quad R \quad E B A N$

19 Date of deposition: Jan. 19, 2007, 1:30 P.M.

21 For the Petitioner: Ellen Jones

22 For the Defendants: Thomas Conaway

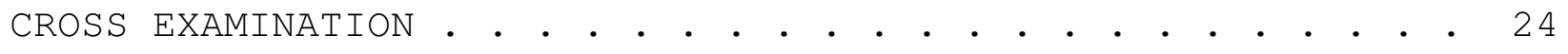


1 Mr. Conaway: Ok, let's open the record. We are here today to

2 take the deposition of the Plaintiff, Margaret Rubin, who is

3 present today with her counsel, Ellen Jones. First let us swear

4 the witness.

$5 \quad$ [Witness is sworn]

6 Okay, Ms. Jones, the usual stipulations?

7 Ms. Jones: Yes, we agree that all objections except as to

8 the form of the question are waived until time of trial.

9 Mr. Conaway: Fine. Ms. Rubin, I'm sure your counsel has

10 explained what is going to happen here today, but just to be sure

11 that you and I understand each other, we're here to learn about

12 the facts of this case, what actually happened. I'm not trying to

13 trick you or mislead you or get you to say anything that isn't

14 true, okay? I just need to know what happened here so we all know

15 what the facts are before we go to trial, or before the judge. So

16 what I'm saying is that if I ask you a question that you don't

17 understand, or that you think is confusing or misleading, please

18 feel free to ask me to rephrase the question or explain it, okay?

19 I don't want there to be any misunderstandings here.

20 THE WITNESS: Fine.

21 Mr. Conaway: Great. Let's get started

22 DIRECT EXAMINATION

23 BY Mr. Conaway:

24 Q: Can you give us your full name and address, please? 
1 A: Meg Rubin, 242 Kiler Way, Old York City.

2 Q: And how old are you?

$3 \quad \mathrm{~A}: \quad I^{\prime} m 41$.

4 Q: Are you currently employed?

5 A: Yes, I'm an artist and a professor of fine arts at Old York

$6 \quad$ University.

7 Q: How long have you been employed there?

8 A: I've been teaching for 15 years, the last eight at old York.

9 I've been painting since I was a child.

10 Q: And I understand you are not married?

11 A: No I am not.

12 Q: Have you ever been married?

13 A: I think so.

$14 \mathrm{Q}$ : Let me rephrase the question. Have you ever been united in 15 matrimony recognized by the state of Old York?

16 A: Again, I think so. I joined my partner in a civil union in 17 Vermont on July 13, 2000. I think Old York is legally 18 required to recognize that union, or should be at least.

19 Q: Ok, let's start from the beginning here. Are you a lesbian? 20 A: Yes.

21 Q: How long have you been a lesbian?

22 A: All my life, I guess. I didn't just decide one day to become 23 lesbian.

24 Q: I'm sorry, what I meant was how long have you been openly 
$1 \quad$ lesbian?

2 A: I think people have always known.

3 Q: When did you first begin identifying yourself publicly as $4 \quad$ lesbian?

5 A: I don't see what that matters.

6 Ms. Jones: Meg, this may not be relevant to any issue, but

7 we've agreed to waive objections like this until the time of

8 trial, just to speed things up here a bit.

9 By Mr. Conaway:

10 Q: Can you answer the question?

11 A: I started living with my partner about eight years ago. In 121999.

13 Q: That would be Francie Kohler?

14 A: Yes.

15 Q: Again, I don't mean to pry, but the nature of your 16 relationship with Ms. Kohler may have some relevance to the 17 suit you have brought, so could you tell me a bit more about 18 the nature of your relationship with Ms. Kohler?

19 A: I met Francie at an art exhibit of mine in old York about 12 20 years ago, and we immediately fell in love. I was living 21 downstate at the time, and wanting to be with Francie was a big part of the reason I applied for the job at old York U. 23 As soon as I got that job I moved in with Francie here. 24 Q: When was that? 
1 A: The summer of 1999.

2 Q: Were the two of you open about your relationship? Publicly I mean?

4 A: Yes, absolutely. We'd go to parties together, social gatherings for her job and for mine, go out on the town together. The usual stuff that partners do. We didn't try to hide our relationship from anybody.

8 Q: Were you monogamous with Francie?

9 A: Absolutely. We were committed to each other and we were 10 faithful to each other.

11 Q: You mentioned that you had a civil commitment ceremony in $12 \quad$ Vermont?

13 A: Yes, and a religious commitment ceremony.

14 Q: When was that?

15 A: In 1999, we had a public commitment ceremony in front of 16 Father Roger Smith.

17 Q: What denomination is Father Smith?

18 A: He's an Episcopal priest, and he sanctified our commitment 19 to each other, in front of our friends, our family, and in 20 the eyes of God.

21 Q: That's about the same time you moved to Old York?

22 A: We had the ceremony before I moved in with Francie. After 23 the ceremony we took a honeymoon and when we came back we 24 began living together. 
1 Q: Then in 2000 you went to Vermont?

2 A: Yes, after Vermont passed its civil union law, we went to

$3 \quad$ Vermont and got married.

4 Q: You had a civil union ceremony in Vermont?

5 A: Yes, July 13, 2000.

6 Q: Ok, let's back up a little bit. First, did either you or

Francie have any children prior to Johnnie?

$8 \quad \mathrm{~A}: \quad$ No.

9 Q: When did you decide you wanted children?

10 A: Well we both loved children and always talked about adopting 11 a child, but Old York wouldn't let us do that, so we decided 12 that we would try artificial insemination.

13 Q: How did you decide which of you would carry the child?

14 A: Well I had always wanted to know what it was like to be 15 pregnant and feel that life growing inside of me, and

19 Q: I don't mean to interrupt, but what was Francie's job?

20 A: She was vice president of marketing for Beautimous Cosmetics. She was a real career woman, she would have been president of the company if she-MS. Jones: Do you need a minute?

24 THE WITNESS : 
1 A: No, I'm fine, I'm sorry. I still miss her.

2 Q: I'm sorry to have interrupted you, Ms. Rubin. You were describing the decision to become pregnant?

4 A: So anyway I got tested by the fertility doctor and he told me I could not become pregnant, that my eggs were not viable or something, I didn't really understand what he was saying. The bottom line was that I couldn't get pregnant, and fertility drugs sounded like they had too many side effects that I did not want to risk.

10 Q: So Francie agreed to?

11 A: Yes. She wanted a child as badly as I did, so it was really 12 an easy decision for her.

13 Q: Who donated the sperm?

14 A: We decided to use an anonymous donor so there wouldn't be 15 any issue about paternity claims. The fertility doctor had a 16 procedure for that and we decided that would be best, since 17 the child was going to be ours and we did not want any 18 complications.

19 Q: So Francie became pregnant?

20 A: The doctor did an in vitro thing and placed the fertilized 21 egg in Francie's womb, and she gave birth to Johnnie.

22 Q: When was Johnnie born?

23 A: May 5, 2003. I was there in the delivery room with her. It's 24 the closest thing to a miracle we can ever see on this 
1 earth.

2 Q: Ok. I assume Francie took some time off from the cosmetic 3 company to care for Johnnie?

4 A: The company gave her maternity leave like they would any 5 other employee, although Francie was always on the phone 6 during those two months keeping her office running. Like I 7 said, she was a real go-getter in the office.

8 Q: She stayed home for two months after Johnnie was born?

9 A: Yes, and I took a sabbatical from the university that fall

10 too so I could stay home with Johnnie even after Francie 11 started going back to the office.

12 Q: Tell me about Francie's death.

13 A: [no response]

14 Q: I'm sorry, do you need a glass of water?

15 A: I'll be okay. It still hurts, you know. It was two years 16 ago. A cabbie in a hurry, you know how it goes in Old York 17 City, too many people, too many distractions. Francie was 18 crossing the street when the cabbie ran the red light and 19 killed her.

20 Q: I understand this is hard. Did Francie leave a will?

21 A: No.

22 Q: Did she leave a power of attorney?

23 A: No.

24 Q: Were you appointed legal guardian of Johnnie in any way? 
1 A: Well we considered ourselves married. We didn't think we needed anybody's permission for me to love and care for our son .

4 Q: I understand. I'm only asking if you ever took any steps, legal measures, to get guardianship or legal custody of Johnnie.

7 A: No we didn't think we needed to.

8 Q: Ok. Fine. At some point you filed a petition to adopt Johnnie however. Why did you do that?

10 A: Well I got a letter from children's service saying that 11 Johnnie was a dependent child, that he had no mother and 12 that I should bring him in so they could put him in foster 13 care. I mean of all the--

14 Ms. Jones: Careful Meg. Take a deep breath.

15 A: I'm sorry. This just makes me so angry.

16 Q: So what did you do?

17 A: Well of course I wrote back and told them that Johnnie is 18 not dependent, that I am his mother and that I would not let 19 them take him away from me. And then I hired a lawyer.

20 Q: And she advised you to file adoption papers?

21 By Ms. Jones: Objection. Attorney client privilege.

22 Q: Fair enough. You filed this adoption proceeding soon after 23 consulting with legal counsel?

24 A: Yes. 
1 Q: Even though the law of Old York prohibits homosexuals from adopting?

3 A: She told me the law was unconstitutional and that she'd fight it for me.

Ms. Jones: Meg, let's not talk about what I told you, okay?

6 That's privileged.

7 Q: So you filed your petition to adopt Johnnie.

8 A: Yes.

9 Q: What happened then?

10 A: Well there was a lot of paperwork involved, and then Delia 11 came by the house to do a home visit to see if I was a fit 12 mother, and she asked all kinds of questions including 13 whether I was a homosexual.

14 Q: And what did you tell her?

15 A: I told her about my marriage to Francie.

16 Q: Are you currently a practicing homosexual?

17 A: Why is that any of your business?

18 Q: Well this is your petition to adopt, and the state law makes 19 homosexuality an issue, so you need to answer my question. 20 Ms. Jones: Objection. I think this question has already been 21 asked and answered.

Mr. Conaway: I didn't hear an answer.

23 MS. Jones: At the beginning of the deposition. You asked her 24 if she was a lesbian and she said yes. 
1 Mr. Conaway: I'm getting more specific right now, asking

2 whether she has any current homosexual involvement with other

3 women. I think it bears on whether this adoption is in the best

4 interest of the child.

5 MS. Jones: I dispute whether it has any relevance whatsover,

6 but since we have waived relevance type objections until the time

7 of trial I will instruct my client to answer the question. But

8 let's please move on to more relevant matters.

9 BY THE WITNESS :

10 A: I have not been with anybody since Francie died. Satisfied?

11 Q: But you still consider yourself a lesbian?

12 A: I don't know what you mean by consider myself. I am what I

13 am. I didn't choose to be gay. I am gay. This is who I am.

14 Q: Fine. Thank you. Is it your intention to raise this child as

15 a single woman?

16 A: It is my intention to raise my child. I don't know what the

17 future holds for me. I'm not ruling anything out. Right now

18 I'm still hurting over Francie. I'm going to love my child

19 and raise him the best way I can.

20 Q: Did Francie leave any heirs other than Johnnie?

21 A: Her mother is still alive.

22 Q: What is her name?

23 A: Stella Kohler.

24 Q: Where does she live? 
1 A: She lives in Old Rochelle, downstate.

2 Q: Have you discussed with her the possibility that she would take Johnnie in?

4 A: I have not discussed it with her, directly. She and I don't 5 see eye to eye, you might say.

6 Q: Was there friction between her and you because of your relationship with Francie?

8 A: You could say that.

9 Q: Can you explain?

10 A: Stella never accepted that Francie was gay, and she blamed 11 me for quote corrupting her daughter.

12 Q: Has Stella offered to take Johnnie in?

13 A: Not that I know of. In fact Delia told me that Stella 14 doesn't want him. Stella is not in good health. She's in her 15 seventies and has emphysema from smoking too much, and she can't take on a child anyway. She was never very close to $17 \quad$ Francie.

18 Q: What was the outcome of your adoption petition?

19 A: I got a letter from Delia--

20 Q: That would be Delia Clarke, the respondent in this case? 21 A: Yes, Delia from children's services. She wrote to me and said my petition had been denied because I was gay and the statute did not allow gay people to adopt children, and that they would place Johnnie in foster care as soon as 
$1 \quad$ arrangements could be made for him.

2 Q: Johnnie is still living with you?

3 A: Yes he is.

4 Mr. Conaway: I believe those are all the questions I have.

5 Thank you.

6 CROSS-EXAMINATION

7 BY MS. Jones:

8 Q: Just a few more questions for you Meg, I know this is hard 9 for you.

10 A: Thank you.

11 Q: Before Francie died, were you involved with Johnnie's care?

12 A: Absolutely.

13 Q: Can you tell us how?

14 A: Well I was the one who spent the most time with him. Not to 15 speak ill of Erancie, she was a wonderful mother, but she 16 had an important position at a big company and she made a 17 lot of money there. She worked long hours and my schedule at 18 the university was much more flexible, so I switched from a 19 full-time professor to part time so I could stay home with 20 Johnnie. It's the one thing she hated most about her job, 21 that it took her away from Johnnie too often.

22 Q: Was Johnnie ever in day care?

23 A: No. We had a babysitter come over a couple of days a week, 24 when I had classes to teach or work to do at the university, 
1 but most days when I didn't have to go to the school I

2 stayed home with Johnnie.

3 Q: Is that still true?

4 A: No. I've taken a leave of absence from the university while 5 all of this is going on, so I'm with Johnnie full time now.

6 Q: While Francie was alive, what was Johnnie's relationship $7 \quad$ with her?

8 A: Johnnie loved Francie as much as he loved me. He called us 9 both Mommy .

10 Q: Does he still call you Mommy?

11 A: Oh yes, absolutely.

12 Q: Now I apologize for this question, but we need to know what 13 your plans are. I know Johnnie is still an infant, but do 14 you plan to encourage Johnnie to become a homosexual when he $15 \quad$ grows up?

16 A: Absolutely not. First, I don't think people become 17 homosexuals; I think they are what they are. I really don't 18 care whether Johnnie is homosexual or heterosexual, he is my 19 son and I love him for whoever he is and I will encourage 20 him to be the person he was meant to be. I want him to 21 respect everybody and not pass judgment on people, and to be 22 a good honest boy and man.

23 Q: Thank you. That's all I have. 24 [The deposition was concluded at $2: 35$ p.m.] 


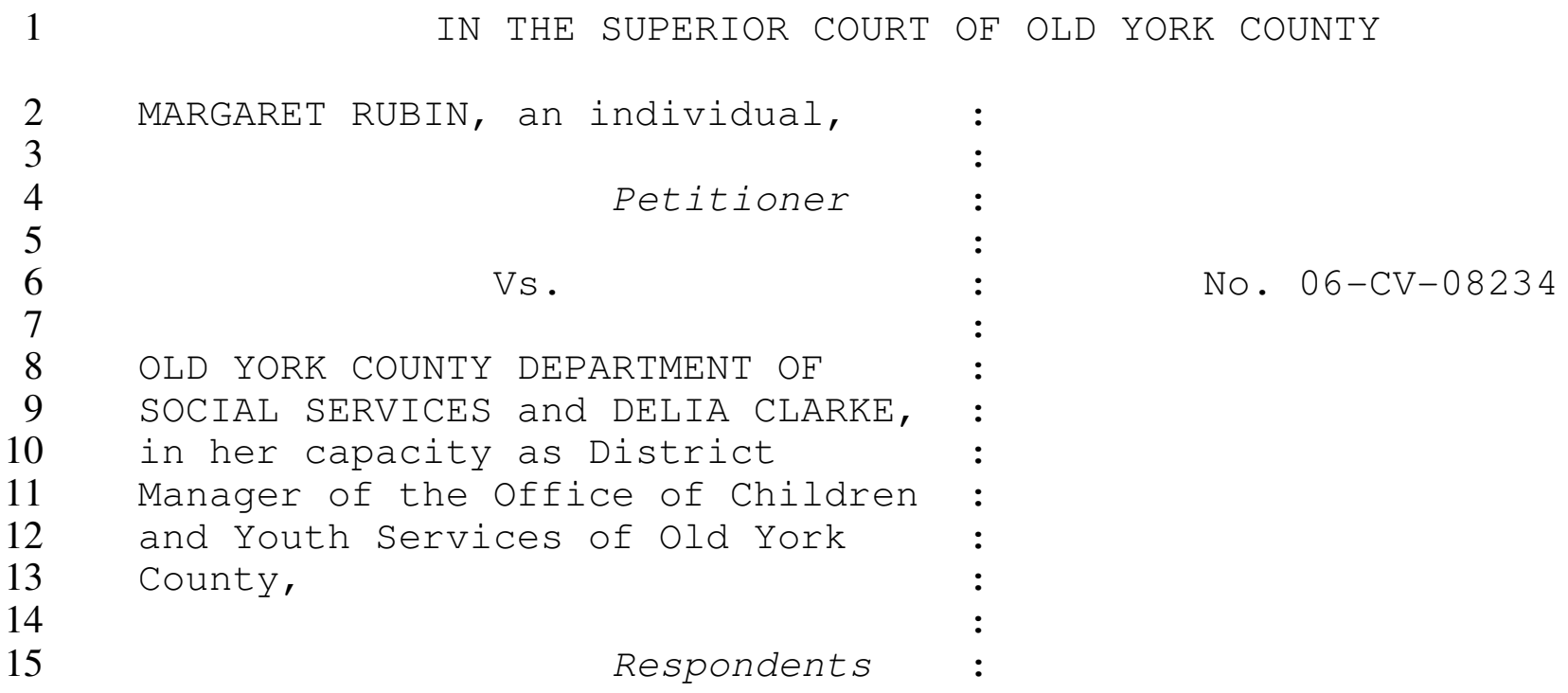

16

19 Date of deposition: Jan. 19, 2007, 3:00 P.M.

21 For the Plaintiff:

Ellen Jones

22 For the Defendants: Thomas Conaway 


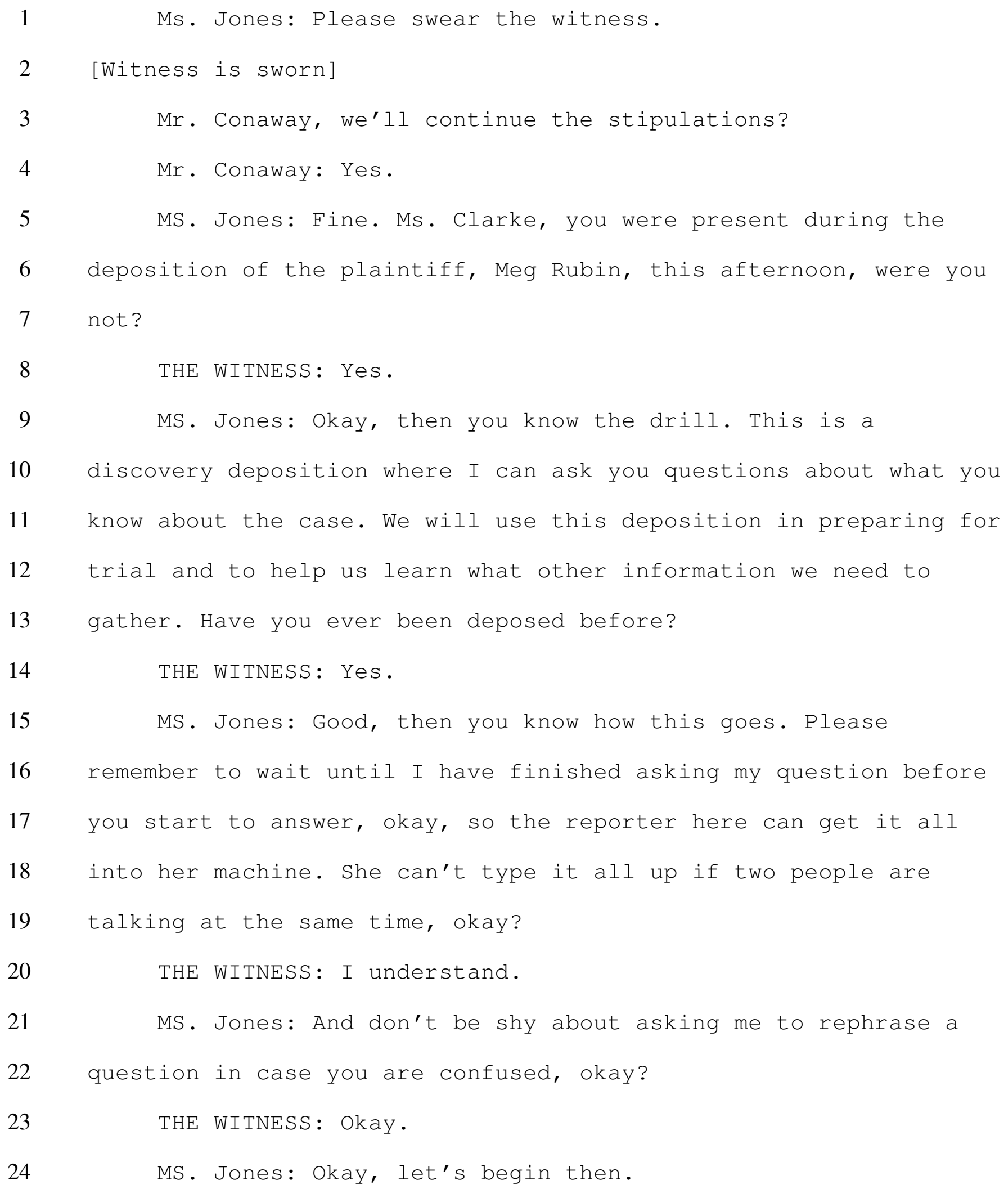




\section{DIRECT EXAMINATION:}

2 BY MS. Jones:

3 Q: Please state your name, office address and occupation.

4 A: My name is Delia Clarke. My office is located in the City

5 County Building, on First Avenue in downtown Old York City.

$6 \quad \mathrm{Q}:$ And your occupation?

7 A: Yes, I'm sorry. I am a caseworker for the Office of Children

8 and Youth.

9 Q: Is that a city government department?

10 A: No, it is a department of old York County government.

11 Q: Ok. And what is your official title?

12 A: Well, technically I am the director of the office of

13 Children and Youth, which is a branch of the Old York County

14 Department of Social Services.

15 Q: How many caseworkers do you have in the Office of Children

16 and Youth?

17 A: There are twenty front-line caseworkers.

18 Q: And you are the supervisor of the department?

19 A: Yes.

20 Q: Then you're not what you referred to as a front-line $21 \quad$ caseworker?

22 A: Not technically, although I do some cases myself when 23 needed.

24 Q: So as director of the Office of Children and Youth, you do 
not maintain a regular case load, like the people you supervise?

3 A: No. I handle mostly special cases, and a much lower load than the caseworkers since I have supervisory duties as well.

6 Q: What sorts of cases does your office handle?

7 A: Well by far the largest number of cases deal with child called upon to do an investigation into allegations of abuse, make a determination as to whether the allegation is founded or not, and if so, to take appropriate measures to protect the children who are at risk.

Q: I understand. What role does your office play in adoption cases?

A: Okay. When a petition for legal adoption is filed, we are asked to do a family study, to investigate the proposed adoptive parents to see if they are fit parents, what kind of environment the adoptee would be going into, and make a recommendation to the court.

Q: Procedurally how do you handle such cases?

A: Well as soon as we get the adoption petition, we assign a caseworker to the petition and he or she then reviews the application, does a background check through the county records office, gathers whatever information is available 
13 Q: And what happens if you conclude that the parent is not, or

19 A: Yes.

$20 \mathrm{Q}$ : Why is that? How did that happen?

21 A: Well as I said I sometimes take on special cases, and we

about the prospective adoptive parents. Eventually the caseworker schedules an interview in the applicants home and then conducts any follow-up investigation that might be needed.

Q: What happens if you conclude that the parents would be proper parents?

A: The caseworker writes a report which goes to the family court judge, and the judge then schedules a hearing.

Q: And is the adoption then granted?

A: Usually the judge follows the recommendation of the caseworker, although the judge is always free to disagree with us. parents, viable candidates or good parents?

A: We would write a report rejecting the application and the matter would not be sent to the judge.

Q: Let's talk specifically about this case. First, you handled this one personally, right? knew right away that this was going to be a high-profile case, given who the mother was and the nature of the relationship that she had with the applicant. 
1 Q: Can you be more specific?

2 A: Well, Francie Kohler was pretty well-known, and her death was all over the news when it happened, and of course everybody knew that Francie had an intimate relationship with the applicant, so when we saw the petition for adoption come in we expected the media to be all over it, which of course they have been.

8 Q: You knew that Francie Kohler was a lesbian?

9 A: Yes, it was generally known.

10 Q: And that Meg Rubin was her partner?

11 A: Yes.

12 Q: When Francie died, why didn't your office take action immediately to put the child in foster care?

14 A: Well we didn't really know whether Francie had left a will, 15 whether the child had gone to live with family members, whatever. We didn't have a complaint of child abuse to investigate, and we have pretty full case loads, so we just

21 Q: At some point you were contacted by Francie's mother, weren't you?

23 A: Yes, we got a letter from stella Kohler saying that Johnnie was living with a woman to whom he was not related, and 
1 wondering what we were going to do about it.

2 Q: And what did you do about it?

3 A: We contacted applicant to verify that Johnnie was living

12 Q: Why was it likely to get sticky?

13 A: It was pretty much common knowledge that Francine Kohler was 14 a lesbian, but Ms. Rubin failed to answer that question on the adoption petition, so we were afraid there was going to

17 Q: Okay, so what did you do?

18 A: Well, I made sure that I handled the case just as I would 19 any case. I conducted the usual search of records, the 20 preliminary investigation--

21 Q: What did you find?

22 A: No problems. She, Ms. Rubin, was not in debt, no judgments 23 against her, no litigation against her, no criminal record, 24 nothing negative at all popped up in our records search. 
1 Q: Did you interview her?

2 A: Yes, I conducted an extensive interview with her at her 3 home.

4 Q: The home on Kiler Way?

5 A: Yes.

6 Q: What did you find?

7 A: Well the home is lovely, a very large home with a large yard

8 in a very exclusive neighborhood, a gated community

10 in back for the child.

11 Q: How about your interview with my client? What were your 12 impressions?

13 A: I was impressed that Ms. Rubin was a devoted mother, that 14 she loves Jonathan very much, was very attentive to him. I 15 observed her interacting with him throughout the interview 16 and in every respect she appeared to be modeling appropriate 17 behavior, treating him in an age appropriate manner.

18 Q: Did you make any observations about Jonathan's feelings 19 about my client?

20 A: He appeared to be acting in a very age appropriate manner. 21 He was shy around me at first, staying very close to Ms. 22 Rubin, but as she let him know that I was not a threat to 23 him he began to play normally and seemed to be quite happy. 24 Q: Did you observe anything in his behavior that led you to 
1 believe he had been abused or was in any distress or danger?

2 A: No not at all; he appeared to be a normal, happy, healthy

3 young boy. He appeared to be quite attached to his mother.

4 Q: Not inappropriately so?

5 A: No not at all, just like any three-year-old would be when

7 Q: Did you ask about my client's sexual orientation?

8 A: Yes I did.

9 Q: What was her response?

10 A: She was very candid that she had lived with Ms. Kohler since 1999 as her lover. She did say that she did not believe that 12 her sexual orientation had any bearing on her ability to be 13 a good mother to Jonathan.

14 Q: Did you inquire further?

15 A: I asked her if she was still a homosexual, and she became 16 somewhat defensive.

17 Q: Can you be more specific?

18 A: She said her sexual orientation was irrelevant.

19 Q: What was your conclusion at the end of the interview?

20 A: That she was a homosexual.

21 Q: Other than her sexual orientation I mean. Let me ask it this way: other than the fact that she admitted to being homosexual, did you consider her to be a fit parent?

24 A: Yes. 
$1 \mathrm{Q}$ : And if she were a heterosexual, you would have recommended $2 \quad$ granting the adoption petition?

3 A: Yes.

4 Q: She had appropriate skills, means, desire to raise good, $5 \quad$ healthy children?

6 A: She appeared to, yes.

7 Q: So her sexual orientation was the only reason her $8 \quad$ application was denied?

9 A: I would have to say yes.

10 Q: Ok. How did it go from there?

11 A: Well I told her at the end of the interview that I would 12 have to review this matter with the DSS, my superiors, and 13 possibly legal counsel as well, and that we would get back 14 to her.

15 Q: Ok, and did you do that?

16 A: Yes. I brought the case to the next DSS staff meeting and we 17 discussed it, and we also ran it by the county attorney's $18 \quad$ office.

19 Q: When you say DSS staff meeting--

20 A: Other department heads. I'm the director of the Office of 21 Children and Youth; we have other offices, like drug and 22 alcohol, mental health, etcetera, and all of the department 23 heads meet once a week to talk over issues and problems and 24 just general business. 
1 Q: And the consensus was what?

2 A: Everybody, including the county attorney, told me I had to 3 enforce the statute.

$4 \quad$ Q: Meaning what?

5 A: That we had to deny the adoption.

6 Q: And you so advised my client.

7 A: The department head did, Ms. Bryant.

8 Q: The letter of Dec. 19, 2006?

9 A: Yes.

10 Q: Okay in that letter Ms. Bryant told my client that Jonathan 11 would be taken from her and placed in foster care, right?

12 A: Well we had a situation in which a person with no legal 13 right to raise the child had custody of the child, and she 14 had no legal right to make decisions for the child, enroll 15 him in school, make medical decisions, all of the things 16 that parents do for their children, so at that point we had 17 to take action to protect that child.

18 Q: He was not then in any danger though was he?

19 A: No, that's not what I mean, he was physically safe and being 20 cared for, but it was a legal situation and we had to resolve it. And the only way we could do that was to place the child in foster care and seek adoptive parents for him.

23 Q: Did you investigate placing him with relatives of Francie $24 \quad$ Kohler? 
$1 \quad$ A : Yes.

$2 \mathrm{Q}:$ When?

3 A: Even before we sent the letter. We were hoping to be able to

11 Q: So the only option left was foster care?

12 A: Yes.

13 Q: Did you look into whether a member of my client's family 14 would be an appropriate placement?

15 A: No. I mean, why should we? Ms. Rubin had no legal authority with respect to Jonathan, so why would her family have any rights here?

21 outburst.

22 BY MS. Jones:

23 Q: Let's change the subject here a little bit. If DSS wins this 24 case, Jonathan would go into foster care, right? 
1 A: Yes.

2 Q: And then be placed for adoption?

3 A: Yes.

4 Q: Would the pool of potential adoptive parents be limited to $5 \quad$ Old York County, or the entire state of old York?

6 A: We would first look for adoptive parents in old York County, but in some circumstances we have cooperative agreements with other counties and might place children there.

9 Q: How often does this happen?

10 A: It is rare. Maybe one every two or three years. Remember, 11 the number of children we have responsibility for always 12 exceeds the number of eligible parents willing and able to 13 adopt. Other counties have similar situations so there are 14 not a lot of applicants knocking on our door.

15 Q: Do you ever approve single parents for adoption?

16 A: Yes.

17 Q: Single heterosexual parents?

18 A: Yes. We can not allow homosexuals to adopt children, 19 according to the law.

20 Q: On average, what percentage of adoptions in a year are by $21 \quad$ single heterosexul parents?

22 A: It varies, but probably averages around 30, 35\% percent. 23 Q: About a third of all adoptions in an average year? 24 A: That's about right. 
1 Q: You said there are more children waiting to be adopted than you have eligible parents. From the time a child enters the foster care system, what is the average time before a child $4 \quad$ is adopted?

5 A: Well that varies greatly, depending on a lot of factors.

$6 \quad Q:$ Such as?

7 A: The age of the child. The race. Special needs.

8 Q: Illness, like that?

9 A: Yes. Learning disabilities, etc. Special needs adoptions 10 generally take the longest, they usually take years.

11 Q: Are babies adopted more quickly?

12 A: Healthy babies are generally adopted fairly quickly. After 13 they're two or three years old, the wait is usually longer. 14 Teenagers sometimes never get adopted, and leave the foster 15 care system when they attain the age of majority.

16 Q: What is the median time a child, any child, is in the foster $17 \quad$ care system?

18 A: From placement to adoption, for all children, our statistics 19 show a median of 18 months.

20 Q: What about a three-year old child like Jonathan?

21 A: If you take the babies and young toddlers out of the statistics, the median time is four years.

23 Q: How many children never get adopted and simply leave the $24 \quad$ system at the age of 18 ? 
1 A: Our statistics show about 5\% of children never get adopted. MS. Jones: Okay, thank you. That's all I have. Mr. Conaway: I have no questions. We're done.

4 [The deposition was concluded at 4:05 p.m.] 


\section{IN THE SUPERIOR COURT OF OLD YORK COUNTY}

\begin{tabular}{|c|c|}
\hline Petitioner & \\
\hline Vs. & No. 06-CV-08234 \\
\hline OLD YORK COUNTY DEPARTMENT OF & \\
\hline SOCIAL SERVICES and DELIA CLARKE, & \\
\hline in her capacity as District & \\
\hline Manager of the Office of Children & \\
\hline and Youth Services of Old York & \\
\hline County, & \\
\hline Respondents & \\
\hline
\end{tabular}

\section{ORDER AND JUDGMENT}

McCLAREN, District Judge

On December 28, 2006, the Petitioner, Margaret Rubin, filed a Notice of Appeal seeking to reverse a finding by the Respondent Old York County Department of Social Services that Jonathan Kohler was a dependent child, denying her petition to adopt Jonathan, and directing her to surrender the child so that he could be placed in foster care. The notice of appeal raises three issues: (1) whether Petitioner is legally Jonathan's mother by virtue of a so-called "civil union" entered into between Petitioner and Jonahan's birth mother; (2) whether the Old York statute prohibiting homosexuals from adopting children violates the Due Process clause of the $14^{\text {th }}$ Amendment; and (3) whether the statute violates the Equal Protection clause of that same amendment. The court denies the appeal on all three grounds.

\section{Background}

Rubin resides in Old York City, Old York. She is an artist and art professor at Old York University. She is also a lesbian. On September 9, 2006, Rubin's lesbian partner, Francie Kohler, was killed in a traffic accident when a taxi struck her while she was crossing the street at a crosswalk. Kohler was a well-known executive at the cosmetics company Beautimous. At the time of Kohler's death, she was in a lesbian relationship with Rubin. They claim to have been joined in a civil union in Vermont in July 2000.

Throughout their relationship, Kohler and Rubin cohabited in Old York City. In 2002, the couple decided that they wanted to have a child. They agreed that Kohler would bear the 
child. Kohler became pregnant through artificial insemination. On May 5, 2003, Kohler bore Jonathan Kohler.

Prior to Kohler's death, Rubin did not seek to adopt Jonathan or become his legal guardian.

Kohler died intestate and left no instructions about Jonathan's custody in the event of her death. Kohler's mother, Stella, who was appointed administratrix of Kohler's estate, contacted the Old York County Department of Social Services ("DSS") to report that Johnnie was then living with a woman who was unrelated to him. DSS investigated and, upon verifying those facts, notified Rubin that Johnnie was a dependent child and asked her to deliver Johnnie to DSS for placement in foster care. Rubin refused, and instead filed an application to adopt Jonathan.

Delia Clarke, the head of the Office of Children and Youth at DSS, scheduled an in-home visit and interview with Rubin. This interview took place on December 3, 2006. As a part of the interview, Clarke asked Rubin a series of questions about her personal background and her parenting skills. During the course of the interview, Clarke asked Rubin whether she was a homosexual. Rubin replied that she was but that she considered her sexual orientation irrelevant to her ability to be a good parent to Jonathan. At the conclusion of the interview, Clarke informed Rubin that her application would be referred to DSS's central office and that Clarke would be in contact with Rubin to let her know the status of the application.

On December 19, 2006, DSS notified Rubin that her application to adopt Jonathan had been rejected, citing Old York Civil Code $\S 19-67-2$ (B) (1978). The letter also requested that Rubin deliver Johnnie to DSS for placement. This appeal followed.

At the present time, Jonathan is still in Rubin's custody.

\section{Analysis}

In this appeal, Rubin asks this court to recognize the validity of a civil union ceremony performed in Vermont. Alternatively, she asks that we declare Section 19-67-2(B) unconstitutional so she may proceed with Jonathan's adoption. We deny on all grounds.

First, the validity of Vermont civil unions has been litigated in Old York. In Charles $v$. Amsterdam, 878 O.Y. 241 (2005), our Supreme Court considered the right of one homosexual partner to inherit the property of his deceased homosexual lover, based on a claim that the men had entered into a civil union in the State of Vermont. The court held that Old York marriage law permitted marriages only between a man and a woman, and noted that earlier that year the voters of Old York had amended the Old York constitution to prohibit the state from recognizing samesex marriages. Since a "civil union" is simply marriage by another name, the Supreme Court held that the Full Faith and Credit clause did not require our courts to recognize arrangements entered into in other states that would be illegal if entered in this state. Since the Charles case was well- 
publicized and predated this petition by more than a year, counsel's arguments on this point border on the frivolous.

Petitioner next claims that the substantive prong of the Due Process Clause of the $14^{\text {th }}$ Amendment gives her a fundamental right to adopt Johnnie. As an initial matter, this court has previously observed that "substantive Due Process is a very slippery slope, and appears to be just a device to allow activist judges to 'discover' rights which they favor but which do not appear anywhere in the text of the Constitution." Ottenson v. Bartleby, No. 451-CV-2001, Superior Court of Old York (August 18, 2001). This case is another example of a litigant inviting the court to intrude upon the legislative function, which invitation the court declines.

Petitioner first argues that the recent case of Lawrence v. Texas, 539 U.S. 558 (2003), establishes the heretofore unknown fundamental right of "sexual intimacy." However, properly read, Lawrence did no such thing, and as a consequence it applied rational basis review. Petitioner next claims that she has a fundamental right to "family integrity," citing such cases as Smith v. Org. of Foster Families for Equal. \& Reform, 431 U.S. 816, 842 (1977) and Troxel v. Granville, 530 U.S. 57, 65, 66 (2000). However, the right to "family integrity" presupposes that a legal family exists in the first place that is entitled to protection. Smith involves a procedural due process claim on behalf of foster parents, and is inapposite here. In Troxel, the court found that a statute giving courts the power to order visitation over the objections of a child's natural mother violated the substantive due process rights of the mother to care of her child. Here there is no blood relationship. Given the absence of any legal "family" here, there is nothing to protect. Accordingly, this court will apply rational basis review.

Old York's asserted interest behind Section 19-67-2(B)—protecting the best interests of children up for adoption by placing them in homes containing a traditional nuclear family with a mother and father-is clearly a legitimate state interest. Lofton v. Secretary of the Department of Children \& Family Services, 358 F.3d 804 (11 ${ }^{\text {th }}$ Cir. 2004). Moreover, the statute's prohibition against homosexual adoption unquestionably bears a rational relation to the state's interest. Id.

Finally, Petitioner alleges that she is being discriminated against because she is a homosexual. She once argues that sexual identity is an intractable characteristic that a person is not free to choose, and that therefore strict scrutiny will be applied. She cites various social science studies which claim to support this proposition. However, it is not necessary to resolve this disputed matter here. Suffice it to say that the Supreme Court has never identified sexual orientation as a "suspect class," and this court is loathe discover a suspect or quasi-suspect classification where the United States Supreme Court has not. Therefore, rational basis review is appropriate, and for the reasons already stated, the Old York adoption law is rationally related to a legitimate state interest.

Since Section 19-67-2(B) does not run afoul of the Equal Protection Clause or the Due Process Clause, the statute must be enforced. 


\section{ORDER}

For the reasons stated, the Petitioner's appeal is denied. Petitioner shall forthwith deliver custody of Jonathan Kohler to the Old York County Department of Social Services, Office of Children and Youth, for placement in an appropriate foster home, to await adoption by a heterosexual couple or individual. This Order is stayed for 30 days to allow the parties to make appropriate arrangements to transfer custody. If Petitioner appeals this decision to the Old York Court of Appeals, this order will be further stayed pending the outcome of that appeal.

Jurisdiction retained to ensure compliance with this Order.

Entered: March 3, 2007

Malcolm McClaren, Judge

Old York County Superior Court 
Old York Civil Code

Title 19, Chapter 67 - Adoption

$\S$ 19-67-2 Persons eligible to adopt

(A) The following persons are eligible to adopt:

(1) A husband and wife together; or

(2) An adult who is not married.

(B) Homosexuals are not eligible to adopt under this statute. 